\title{
PENGARUH PEMBANGUNAN SEKTOR PERTANIAN TERHADAP DISTRIBUSI PENDAPATAN DAN KESEMPATAN KERJA DI INDONESIA
}

\author{
Yasrizal $^{1}$, Ishak Hasan ${ }^{2}$ \\ ${ }^{1}$ Fakultas Ekonomi, Universitas Teuku Umar, Meulaboh \\ ${ }^{2}$ Fakultas Ilmu Keguruan dan Pendidikan, Universitas Syiah Kuala, Banda Aceh \\ Email: yasrizal@utu.ac.id
}

\begin{abstract}
The purpose of this study was to determine the influence of GDP growth in the agricultural sector to the distribution of income and employment opportunities in the agricultural sector of Indonesia, in the period 1996-2014. This study uses secondary data time series (time series), obtained from the Central Statistics Agency (BPS), and related agencies as well as various data published through various scientific papers are considered to have a correlation and relevance to this study. The results showed that the GDP data processing significant at $\alpha=0.050$ shown in the p-value of 0.000 or significant at 100 percent confidence interval with a positive effect on employment. Where the coefficient of determination (R2) is 0.9943, meaning that GDP has an impact for 99 percent of the agricultural labor opportunities in Indonesia. Meanwhile GDP is significant at $\alpha=0.10$ on income distribution shown in the p-value of 0.000 or significant at 100 percent confidence interval with a positive impact on the Gini ratio. Where the coefficient of determination (R2) is 0.99014, meaning that GDP has a 99 percent influence on income distribution in Indonesia.
\end{abstract}

Keywords: Agricultural Sector, Employment, Income Disparity JEL Classification: O13, E23

\section{PENDAHULUAN}

Sektor pertanian menjadi sektor kunci dalam penyerapan tenaga kerja di Indonesia. Pada tahun 2000 penyerapan tenaga kerja sektor pertanian mencapai 45 persen dari sembilan sembilan sektor yang ada, pada tahun 2015 turun menjadi 33 persen. Sektor pertanian memiliki peranan penting dalam perekonomian Indonesia, hal ini dikarenakan sektor pertanian berfungsi sebagai basis atau landasan pembangunan ekonomi. Keadaan seperti ini menuntut kebijakan pemerintah untuk menyesuaikan sektor pertanian dengan keadaan dan perkembangan yang terjadi di lapangan dalam mengatasi berbagai per- soalan yang menyangkut kesejahteraan bangsa (Tambunan dalam Setyabudi, 2005).

Sejak tahun 1990 hingga saat ini, perhatian pemerintah mulai diarahkan pada sektor industri dan jasa seiring dengan terjadinya transformasi ekonomi dari negara agraris menjadi negara industri. Kondisi seperti ini yang menjadikan peran sektor pertanian mulai menurun dalam struktur perekonomian. Fokus pembangunan ekonomi lebih banyak diarahkan pada sektor industri dan jasa, bahkan yang berbasis teknologi tinggi dan intensif capital. Namun pada tahun 1997/1998 krisis ekonomi menunjukkan bahwa sektor pertanian 
memiliki daya tahan yang cukup tinggi terhadap goncangan ekonomi dibandingkan sektor lain sehingga dapat menyelamatkan pemerintahan dan negara dari kebangkrutan. Kontribusi sektor pertanian pada saat krisis ekonomi dapat dilihat pada Tabel 1 . Kontribusi sektor pertanian terhadap PDB atas harga berlaku tahun 19961014 dapat dilihat pada Tabel 1.

Masalah ketenagakerjaan perlu mendapatkan perhatian dalam perencanaan pembangunan. Penyediaan kesempatan kerja yang luas sangat diperlukan untuk mengimbangi laju pertumbuhan penduduk usia muda yang masuk ke pasar tenaga kerja dan terciptanya kemerataan distribusi pendapatan. Sempitnya lapangan kerja yang tersedia akan menyebabkan terjadinya pengangguran dan ketimpangan distribusi pendapatan yang akan membawa masalah yang lebih besar lagi.

PDRB sektor pertanian terus mengalami pertumbuhan terjadi secara fluktuasi, pada saat terjaninya krisis moneter pada tahun 1998 penyerapan tenaga kerja sektor pertanian mengalami peningkatan sebesar 13 persen, dikarnakan pengaruh dari pemutusan hubungan kerja dari sektor industri, penyerpan tenaga kerja sektor pertanian dari tahun 1996-2014 mengalami penurunan tercatat tahun 2003 jumlah tenaga kerja sektor pertanian sebesar 43.042.104 jiwa menjadi menjadi 38.973.033 jiwa pada tahun 2014, penurunan jumlah penyerapan tenaga kerja disebebkan pertumbuhan sektor industri dan sektor lainnya serta pemanfaatan teknologi sektor pertanian yang lebih baik yang akhrinya lebih kepada mengintensifkan pemanfaatan modal dibandingkan pemanfaatan tenaga kerja.

Tabel 1

Pertumbuhan PDB Sektor Pertanian Atas Dasar Harga Berlaku, Gini Ratio, Dan
Pertumbuan Kesempatan Kerja Sektor Pertanian Tahun 1996-2014

\begin{tabular}{|c|c|c|c|c|c|}
\hline Tiken & 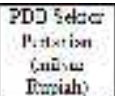 & 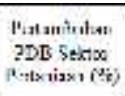 & $\begin{array}{l}\text { Crii } \\
R_{v e w}\end{array}$ & 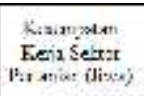 & 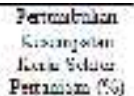 \\
\hline 1396 & sळit3 & & 0,27 & $362195 \% 7$ & \\
\hline Ly: & LJ:TS & {$[1, j$,} & $1, x$ & $\therefore 150641$ & \\
\hline $19 \% 8$ & .7200 & 71,7 & 0,26 & $591+15: 6$ & 1,31 \\
\hline 1795 & 215597 & $2+.5$ & 0.21 & 3S3 9193 & 1.75 \\
\hline 2000 & ItGR+11 & $11: 4$ & i: $x$ & 6017 & +96 \\
\hline $20 \%$ & 251727 & $10, S$ & 0,25 & 3971356 & 2,29 \\
\hline 202 & $3515 \%$ & 1156 & 62 & 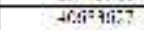 & $\frac{125}{32 t}$ \\
\hline$x=4$ & $10 \% \times=$ & $x \%$ & $i: 2:$ & $4: 4: 114$ & 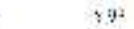 \\
\hline $20: 4$ & 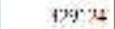 & $i \& 4$ & 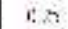 & 40:6:x:17y & $\therefore n$ \\
\hline $\operatorname{son}$ & $16: 4: 9$ & tII $\leqslant$ T & $i: x$ & 4) 60 \% ins & $1: 4$ \\
\hline$x: 6$ & 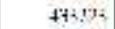 & $18 \approx$ & $: z$ & $401+6,24$ & $\therefore \times 4$ \\
\hline $2 y=$ & בנבנצ & 25,25 & ves & & $\therefore, 6$. \\
\hline 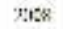 & "tos?a & $\$ 2.4$ & $1: 3$ & $4 ! 3+6 \pi 6$ & II:- \\
\hline$x y$ & n & 14 & 1.5: & 4istix+1: & 1) fas \\
\hline 20.0 & $9 \leqslant 5130$ & 11, te & 0,3 & 1911 & 2,25 \\
\hline 20.1 & J.S1+17 & 10,7 & 0,11 & Gos & 5 \\
\hline $2 \%: 2$ & $1: 15: 4 x$ & $\because 1,32$ & $c, 4 !$ & ES:004 4 & 1,28 \\
\hline 20.3 & 15:0127 & 9.9 & C,11. & 39200251 & 2,92 \\
\hline 20.1 & 1115722 & 10,1 & 6,15 & 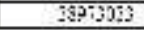 & $2,5 i$ \\
\hline
\end{tabular}

Sumber: Badan Pusat Statistik (BPS) Indonesia, 2016

Berbagai data kependudukan me-mperlihatkan bahwa Indonesia masih mengalami berbagai masalah ketenagakerjaan. Permasalahan tersebut terutama bersumber dari banyaknya penerimaan (supply) tenaga kerja dan rendahnya kualitas sumber daya manusia. Sebaliknya pertumbuhan ekonomi yang dibutuhkan untuk menyerap angkatan kerja tidaklah sebaik apa yang diharapkan, terutama pada sektor pertanian yang merupakan sektor yang menyerap tenaga kerja terbanyak. Tujuan penelitian adalah untuk menganalisis pengaruh pertumbuhan PDB sektor pertanian terhadap penyerapan tenaga kerjapertanian dan distribusi pendapatan di Indonesia.

\section{TINJAUAN PUSTAKA DAN HI- POTESIS}

Kesempatan kerja merupakan hubungan antara angkatan kerja dengan kemampuan penyerapan tenaga kerja. Dalam ilmu ekonomi, kesempatan kerja berarti peluang atau keadaan yang menunjukkan tersedianya lapangan pekerjaan sehingga semua orang yang bersedia dan sanggup bekerja dalam proses produksi dapat memperoleh pekerjaan sesuai dengan 
keahlian, keterampilan dan bakatnya masing-masing. Kesempatan kerja merupakan partisipasi seseorang di dalam pembangunan baik dalam arti memikul beban pembangunan atau menerima kembali hasil pembangunan. Dari definisi ini, kesempatan kerja dapat dibedakan dalam dua kelompok (Sagir, 1995), yaitu :

1) Kesempatan Kerja Permanen, yaitu kesempatan kerja yang memungkinkan seseorang bekerja secara terus menerus sampai mereka pensiun atau tidak mampu bekerja lagi.

2) Kesempatan Kerja Temporer, yaitu kesempatan kerja yang memungkinkan seseorang yang bekerja tetapi dalam waktu yang relatif singkat, kemudian menganggur untuk menunggu kesempatan kerja baru.

Semakin meningkat kegiatan pembangunan akan semakin banyak kesempatan kerja yang tersedia. Hal ini penting karena semakin besar kesempatan kerja atau semakin tinggi kesempatan kerja, maka kemajuan kegiatan ekonomi masyarakat akan semakin baik, dan sebaliknya bila kesempatan kerja semakin rendah maka kemajuan kegiatan ekonomi semakin tidak baik.

Distribusi pendapatan nasional adalah mencerminkan merata atau timpangnya pembagian hasil pembangunan suatu negara di kalangan penduduknya (Dumairy,1997:54).Distribusi pendapatan dibedakan menjadi dua ukuran pokok yaitu; distribusi ukuran, adalah besar atau kecilnya bagian pendapatan yang diterima masingmasing orang dan distribusi fungsional atau distribusi kepemilikan faktorfaktor produksi (Todaro,2000:180).

Dari dua definisi diatas maka dapat ditarik kesimpulan bahwa distribusi pendapatan mencerminkan ketimpangan atau meratanya hasil pembangunan suatu daerah atau negara baik yang diterima masingmasing orang ataupun dari kepemilikan faktor-faktor produksi dikalangan penduduknya.

Salah satu indikator penting untuk mengetahui kondisi ekonomi di suatu negara dalam suatu periode tertentu adalah data Produk Domestik Bruto. baik atas dasar harga berlaku maupun atas dasar harga konstan. PDB pada dasarnya merupakan jumlah nilai tambah yang dihasilkan oleh seluruh unit usaha dalam suatu negara tertentu, atau merupakan jumlah nilai barang dan jasa akhir yang dihasilkan oleh seluruh unit ekonomi. PDB atas dasar harga berlaku menggambarkan nilai tambah barang dan jasa yang dihitung menggunakan harga yang berlaku pada setiap tahun, sedangkan PDB atas dasar harga konstan menunjukkan nilai tambah barang dan jasa tersebut yang dihitung menggunakan harga yang berlaku pada satu tahun tertentu sebagai dasar.

PDB atas dasar harga berlaku dapat digunakan untuk melihat pergeseran dari struktur ekonomi, sedang harga konstan digunakan untuk mengetahui pertumbuhan ekonomi dari tahun ke tahun. PDB adalah nilai barang dan jasa dalam suatu negara yang diproduksikan oleh faktor-faktor produksi milik warga Negara tersebut dan warga Negara asing dalam satu tahun tertentu (Sukirno, 2004). 


\section{Kerangka Pemikiran}

Gambar 2.1

Hubungan Pertumbuhan PDB Sektor Pertanian Terhadap Distibusi Pendapatan dan Kesempatan Kerja Sektor pertanian

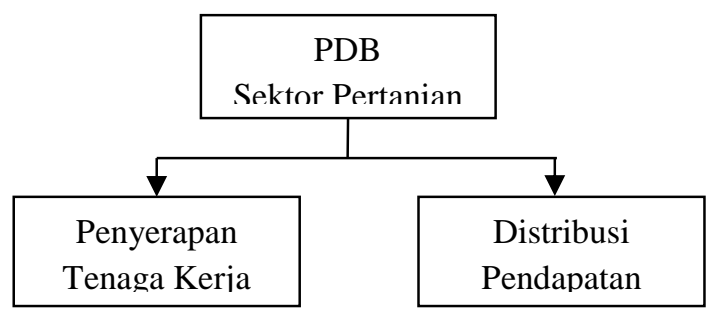

\section{Penelitian Sebelumnya}

Penelitian mengenai pembangunan sektor pertanian terhadaap penyerapan tenaga kerja dan distribusi pendapatan pernah dilakukan peneliti sebelumnya dengan mengunakan berbagai pendekatan dan alat analisis yang berbedabeda yaitu:

1) Fakih (2009) melakukan penelitian selama 1993-2007 tentang pembangunan sektor pertanian terhadap penyerapan tenaga kerja dan distribusi pendapatan. Kesimpulannya bahwa (1) ada pengaruh pembangunan sektor pertanian terhadap penyerapan tenaga kerja di Provinsi Jawa Tengah, (2) tidak ada pengaruh pembangunan sektor pertanian terhadap distribusi pendapatan di Provinsi Jawa Tengah, (3) Ada perbedaan pengaruh pembangunan sektor pertanian terhadap kesempatan kerja di Provinsi Jawa Tengah sebelum dan sesudah revitalisasi pertanian, (4) Tidak ada perbedaan pengaruh pembangunan sektor pertanian terhadap distribusi pendapatan di Provinsi Jawa tengah sebelum dan sesudah revitalisasi pertanian

2) Yamin (2007) melakukan studi tentang analisis pengaruh pembangunan sektor pertanian terha- dap distribusi pendapatan dan peningkatan lapangan kerja di Sumatera Selatan pada tahun 1985-2005. Kesimpulannya adalah distribusi pendapatan masyarakat Provinsi Sumatera Selatan relatif baik dengan nilai indeks gini yang jauh lebih rendah dari satu, pengaruh PDRB masingmasing sub-sektor dalam sektor pertanian terhadap distribusi pendapatan masyarakat tidak berpengaruh nyata, dan PDRB sub-sektor tanaman pangan, perkebunan, pertenakan kehutanan dan perikanan memiliki pengaruh signifikan terhadap kesempatan kerja pada sektor pertanian di Provinsi Sumatera Selatan.

3) Rufaida (2006) meneliti tentang analisis produk domestik regional bruto sektor pertanian dan hubungannya dengan kesempatan kerja serta distribusi pendapatan di Provinsi Sumatera Selatan selama tahun 1985-2005 kesimpulannya adalah PDRB sub-sektor tanaman pangan, perkebunan, peternakan, kehutanan, dan perikanan memiliki pengaruh yang signifikan terhadap kesempatan kerja pada sektor pertanian di Provinsi Sumatera Selatan. Dan Nilai indeks gini berkisar antara $0,25-0,30$ yang berarti ketimpangan pendapatan masih berada pada batas aman. Nilai Rasio modal berpengaruh secara signifikan pada taraf uji 30 persen terhadap distribusi pendapatan.

4) Rompas (2015) melakukan penelitian mengenai potensi sektor pertanian dan pengaruhnya terhadap penyerapan tenaga kerja di kabupaten Minahasa Selatan. Berdasarkan hasil perhitungan 
untuk melihat pengaruh sektor pertanian terhadap penyerapan tenaga kerja di Kabupaten Minahasa Selatan dengan menggunakan analisis regresi sederhana maka dapat disimpulkan berdasarkan hasil analisis tersebut sektor pertanian mempunyai hubungan positif dengan korelasi cenderung kurang terhadap penyerapan tenaga kerja, hal tersebut juga akan mempengaruhi tingkat pengangguran di Minahasa Selatan

\section{METODE PENELITIAN}

Dalam penelitian ini, penulis mengkaji analisi pengaruh pertumbuhan produk domestik bruto sektor pertanian terhadap distribusi pendapatan dan penyerapan tenaga kerja sektor pertanian di Indonesia. Produk domestik bruto sebagai variable bebas, distribusi pendapatan dan kesempatan kerja sebagai variabel terikat.

\section{Jenis Dan Sumber Data}

Penelitian ini menggunakan data sekunder berupa data time series, yang diperoleh di kantor Badan Pusat Statistik (BPS), Dinas Tenaga Kerja, telaah kepustakaan referensi dan sumber-sumber lain yang mendukung penelitian ini. Data yang digunakan selama kurun waktu 19 tahun yaitu dari tahun 1996 sampai tahun 2014

\section{Model Analisis}

Hubungan antara Produk Domestik Bruto sektor pertanian dengan distribusi pendapatan dan kesempatan kerja dapat dilihat dengan mencari nilai regresi antara sub-sektor pertanian yang diwakili oleh Produk Domestik Bruto berdasarkan harga konstan dengan distribusi pen- dapatan dan kesempatan kerja sektor pertanian yang ada di Indonesia, model persamaan yang digunakan yaitu sebagai berikut :

\section{Gini ratio}

Koefisien Gini didefinisikan sebagai $A /(A+B)$, di mana $A$ dan $B$ seperti yang ditunjukkan pada grafik. Jika $A=0$ koefisien Gini bernilai 0 yang berarti pemerataan sempurna, sedangkan jika $\mathrm{B}=0$ koefisien Gini akan bernilai 1 yang berarti ketimpangan sempurna. Koefisien Gini tidak sepenuhnya memuaskan.

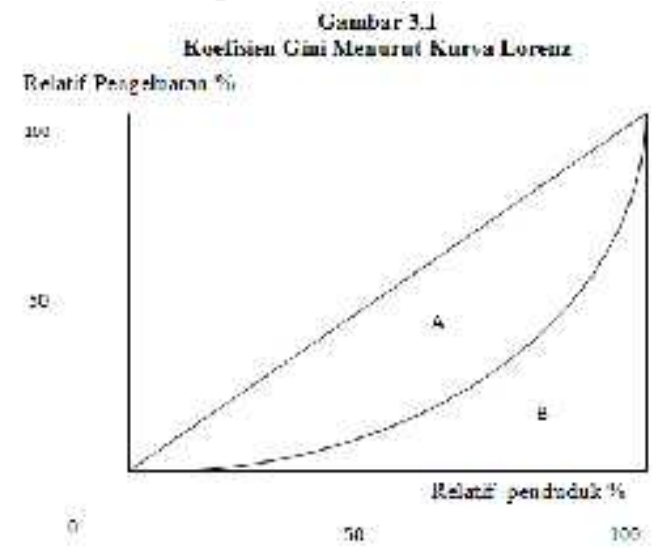

Data yang diperlukan dalam penghitungan gini ratio:

1) Jumlah rumah tangga atau penduduk

2) Rata-rata pendapatan atau pengeluaran rumah tangga yang sudah dikelompokkan menurut kelasnya.

Indikator yang digunakan untuk melihat pemerataan atau distribusi pendapatan adalah dengan menggunakan nilai gini ratio sebagai berikut:

$$
G=1-\sum_{i=1}^{k} \frac{P_{i}\left(Q_{i}+Q_{i-1}\right)}{10.000}
$$

dengan: $\mathrm{P}_{\mathrm{i}}$ : persentase rumahtangga atau penduduk pada kelas ke-i

$\mathrm{Q}_{\mathrm{i}}$ : kumulatif total pendapatan atau pengeluaransampai kelas ke-i

Nilai gini ratio berkisar antara 0 dan 1 , jika: 
$\mathrm{G}<0,3 \rightarrow$ ketimpangan rendah

$0,3 \leq \mathrm{G} \leq 0,5 \rightarrow$ ketimpangan sedang

$\mathrm{G}>0,5 \rightarrow$ ketimpangan tinggi

Tingkat kemerataan menurut Bank Dunia dilihat dari sebaran atau distribusi pendapatan pada kelompok penduduk yang dibagi menjadi 3 , yaitu:

1) 40 persen pertama $\rightarrow$ kelompok kurang beruntung

2) 40 persen kedua $\rightarrow \quad$ kelompok menengah

3) 20 persen ketiga $\rightarrow$ kelompok kaya

Nilai gini ratio yang diperoleh dari kedua model di atas dimasukan ke dalam model persamaan seperti di bawah ini guna mengetahui seberapa besar pengaruh PDB subsektor pertanian terhadap pemerataan distri-busi pendapatan. Untuk analisis model, penulis menggunakan persamaan regresi linear sederhana (Gujarati, 2001) sebagai berikut :

$$
\begin{aligned}
& \mathbf{Y}=\alpha+\beta_{i} X_{i}+e_{i} \\
& \text { dimana : } \\
& \mathrm{Y} \quad=\text { (variable dependent }) \\
& \alpha=\text { Konstanta } \\
& \beta_{\mathrm{i}} \quad=\text { Parameter } \\
& \left.\mathrm{X}_{\mathrm{i}} \quad=\text { (variable independent }\right) \\
& \mathrm{e}_{\mathrm{i}} \quad=\text { Error term }
\end{aligned}
$$

model tersebut diformulasikan lagi untuk menjadi model dalam penelitian ini, sebagai berikut :

$\mathrm{GN}=\alpha+\beta$ PDBsektor pertanian $+\mathrm{ei}$

\section{Kesempatan kerja}

Dari sektor pertanian kesempatan kerja diregresikan terhadap PDB sektor pertanian, dengan model persamaan sebagai berikut.

$$
\begin{aligned}
\mathrm{KK}_{\text {sektor i pertanian }}= & \alpha+\beta \mathrm{PDB}_{\text {sector pertanian }}+\mathrm{ei} \\
\mathrm{Di} \text { mana } & \\
\mathrm{KK}= & \begin{array}{l}
\text { Kesempatan Kerja sektor } \\
\text { pertanian (orang) }
\end{array} \\
\mathrm{PDB}= & \text { Produk Domestik Bruto } \\
& \text { sektor pertanian } \\
\alpha \quad= & \text { Intersep }
\end{aligned}
$$

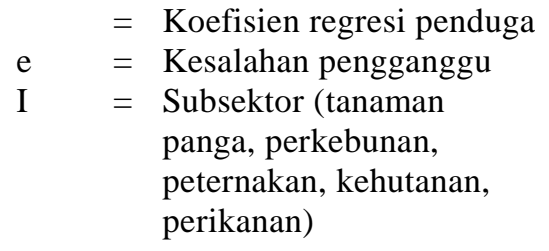

\section{ANALISIS DATA DAN PEM- BAHASAN}

Perkembangan dan kemajuan ekonomi Indonesia dapat dilihat dengan indikator ekonomi makro. Indikator ekonomi makro yang sering digunakan untuk melihat kemajuan ekonomi suatu Negara adalah Produk Domestik Bruto, sedangkan untuk melihat tingkat kesejangan distribusi pendapatan dalam masyarakat indicator yang sering digunakan adalah gini ratio.

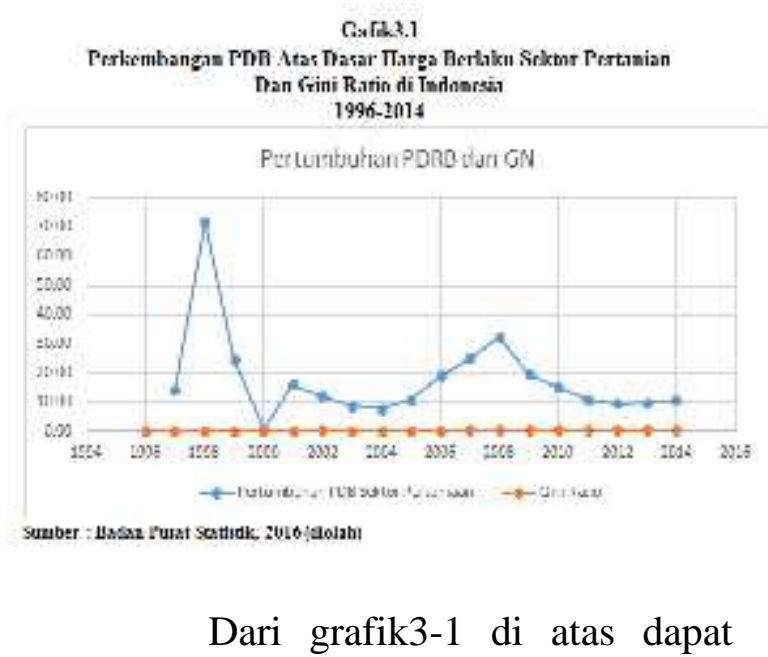
dilihat bahwa Produk Domestik Bruto (PDB) sektor pertanian dari tahun 1996-2014 mengalami pertumbuhan yang stabil, pada tahun 1997, PDB mengalami pertumbuhan sebesar 14,31 persen. Pada tahun-tahun berikutnya jumlah PDB juga terus tumbuh bahkan meningkat, pada tahun 1998 pertumbuhan PDB mencapai 71,69 persen, tahun 1999 juga meningkat sebesar 24,80 persen. Hal tersebut menunjukkan bahwa sektor pertanian tidak terpengaruh oleh krisis ekonomi yang melanda Indonesia pada tahun 1998-1999. 
Menurut data BPS perkembangan nilai indeks gini pedesaaan dari tahun 1996 - 2014 berkisar antara 0,25 sampai dengan 0,31. Nilai ini menunjukkan bahwa tidak terjadi ketimpangan pendapatan yang mengkhawatirkan di Indonesia selama kurun waktu 1996 - 2008. Nilai gini ratio yang tinggi ditunjukkan pada tahun 2007 yaitu sebesar 0,31 dan pada tahun 2002 sebesar 0,29. Nilai yang tinggi ini terjadi akibat adanya peningkatan jumlah penduduk yang berpendapatan tinggi.

Nilai indeks gini ini masih jauh dari nilai satu, dengan kata lain distribusi pendapatan di Indonesia ini relatif baik. Selama periode 19962008, pertumbuhan rata-rata PDB sektor pertanian sebesar 18,85 persen. Walaupun pertumbuhannya tidak stabil, tapi menunjukkan gambaran pertumbuhan PDB sektor pertanian yang baik dalam kondisi perekonomian Indonesia.

\section{Perkembangan PDB Sektor Perta- nian Terhadap Kesempatan Kerja di Indonesia, 1996-2014}

Tenaga kerja merupakan salah satu faktor produksi yang mempunyai peranan penting dalam menciptakan kapasitas produksi barang-barang dan jasa, yang tergolong tenaga kerja ialah penduduk yang berumur di dalam batas usia kerja. Tenaga kerja dipilah ke dalam dua kelompok yaitu angkatan kerja dan bukan angkatan kerja. Angkatan kerja yang tumbuh sangat cepat tentu saja akan membawa beban tersendiri bagi perekonomian, yakni penciptaan atau perluasan lapangan kerja.

Seiring dangan pertumbuhan PDB sektor pertanian kesempatan kerja di sektor pertanian juga tumbuh, ini menandakan bahwa PDB sektor pertanian mempunyai pengaruh positif terhadap kesempatan kerja sektor Per- tanian. Untuk lebih jelasnya, perkembangan Produk Domestik Bruto atas dasar harga berlaku sektor Pertanian terhadap kesempatan kerja sektor pertanian di Indonesia dalam kurun waktu 1996-2014 dapat dilihat pada grafik 3.2

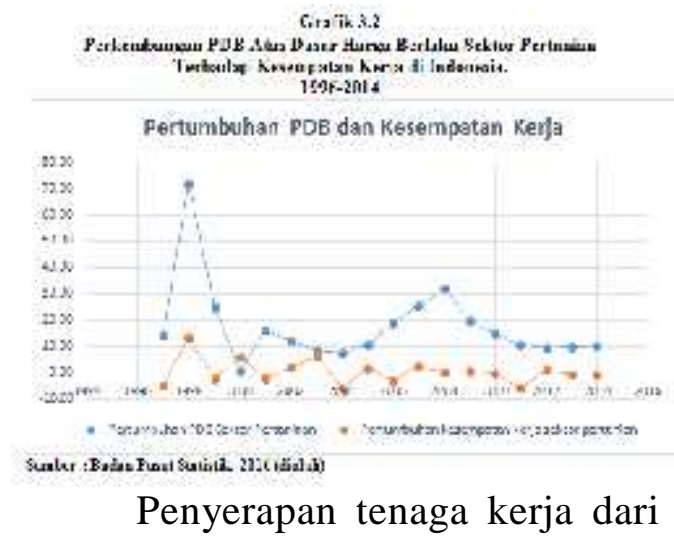
berbagai sektor didominasi oleh sektor pertanian dari tahun 1996-2014. Peranan sektor pertanian dalam kurun waktu tersebut mampu menyerap tenaga kerja lebih besar dibandingkan penyerapan tenaga kerja pada sektor lain yang ada di Indonesia. Penyerapan tenaga kerja sektor pertanian di Indonesia tahun 1996-2014 terus tumbuh dari tahun ke tahun dengan pertumbuhan rata-rata 1,07 persen.

Selama periode 1996-2014, jumlah tenaga kerja yang terserap pada sektor pertanian terus mengalami pertumbuhan dengan persentese pertumbuhannya yang berfluktuasi. Pertumbuhan sebesar 41.961.049 jiwa, dengan rata-rata pertumbuhan 1,07 persen pertahunnya. Walaupun pertumbuhannya tidak stabil, tapi menunjukkan gambaran pertumbuhan yang baik dalam kondisi ketenagakerjaan Indonesia.

Analisis Hasil Estimasi Pengaruh PDB Sektor Pertanian Terhadap Distribusi Pendapatan di Indonesia, 1996-2014

Pengaruh PDB sektor pertanian terhadap distribusi pendapatan 
dapat dilihat melalui uji korelasi antara kedua variabel, dengan menggunakan analisa Regresi linear sederhana, yaitu :

$\mathbf{G N}=0,3158+0.0000000725 \mathbf{P D B}_{\text {sector pertanian }}$

Analisa regresi ini menggunakan program Eviews Version 7,0. Adapun hasil estimasinya dapat dilihat pada Tabel 3.1 berikut ini :

\begin{tabular}{|c|c|c|c|c|c|}
\hline \multicolumn{6}{|c|}{ 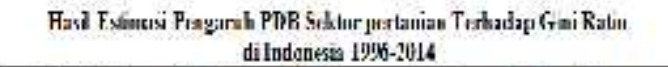 } \\
\hline Taribul & Kutكเsi:u & Sld Errur & in rulw & Evalue & Keltrasyju \\
\hline Kinnsliunfa & $9315:$ & $\sec 7$ & $113 \mathrm{ing}$ & $9,0,3$ & \\
\hline $\begin{array}{l}\text { Produk domestit } \\
\text { brabo [.ШU!! }\end{array}$ & $7.25 \times 10^{4}$ & $8.55 \times 19 ?$ & 7586 & 0,003 & Eigefilyn \\
\hline 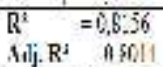 & & DWF & $=17,7$ & & \\
\hline
\end{tabular}

1) Konstanta $(\alpha)$ sebesar 0,3158 , artinya apabila variabel PDB diasumsikan sama dengan nol (0), maka gini rasio rata-rata sebesar0,3158.

2) Koefisien regresi untuk PDB sektor pertanian $\left(\beta_{\mathrm{i}}\right)$ adalah 0.0000000725 , artinya apabila terjadi kenaikan PDB sektor pertanian di Indonesia sebesar 1 milyar rupiah, maka akan menyebabkan meningkatnya nilai gini ratio sebesar 0.0000000725 , dengan asumsi faktor lain dianggap tetap.

3) Koefisien determinasi $\left(\mathrm{R}^{2}\right)$ sebesar 0,8014, artinya PDB memiliki pengaruh sebesar 80,14 persen terhadap pemerataan distribusi pendapatan (gini rasio) di Indonesia, sedangkan sisanya 19,16 persen dipengaruhi oleh faktor-faktor lain di luar penelitian ini.

4) Secara umum Produk Domestik Bruto mempunyai pengaruh yang signifikan terhadap distribusi pendapatan. Hal ini terlihat dari hasil pengujian hipotesis yang ditunjukkan $\mathrm{p}$-value sebesar 0,000 atau signifikan pada confidence interval 100 persen dengan pengaruh positif terhadap penyerapan tenga kerja sektor pertanian.

Analisis Hasil Estimasi Pengaruh PDB Sektor Pertanian Terhadap Penyerapan Tenaga Kerja Sektor Pertanian di Indonesia, 1996-2014 Untuk melihat pengaruh PDB sektor pertanian terhadap penyerapan tenaga kerja sektor pertanian di Indonesia dalam kurun waktu 1996-2014, dapat dilakukan dengan menggunakan analisa Regresi linear sederhana, yaitu :

KK sektor i pertanian $=86021131+$

$21,8463 \mathbf{P D B}_{\text {sector pertanian }}$

Analisa regresi ini menggunakan program Eviews Version 7,0. Adapun hasil estimasinya dapat dilihat pada Tabel 3.2 berikut:

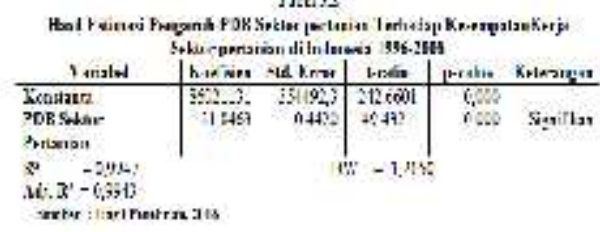

1) Konstanta ( $\alpha)$ sebesar 86.021.131, artinya apabila variabel Produk Domestik Bruto diasumsikan sama dengan nol (0), maka jumlah Kesempatan kerja sektor pertanian rata-rata sebanyak 86.021.131 jiwa.

2) Koefisien regresi untuk Produk Domestik Bruto sektor pertanian $\left(\beta_{\mathrm{i}}\right)$ adalah 21,8463 , artinya apabila terjadi kenaikan Produk Domestik Bruto sektor pertanian di Indonesia sebesar 1 milyar rupiah, maka akan menyebabkan meningkatnya penyerapan tenaga kerja sektor pertaniandi Indonesia sebesar 22 jiwa, dengan asumsi faktor lain dianggap tetap. 
3) Koefisien determinasi $\left(\mathrm{R}^{2}\right)$ sebesar 0,9947, artinya Produk Domestik Bruto memiliki pengaruh sebesar 99,5 persen terhadap penyerapan tenaga kerja sektor pertanian di Indonesia, sedangkan sisanya 0,015 persen dipengaruhi oleh faktor-faktor lain seperti keamanan, investasi, kebijakan pemerintah, dan lainlain. Dengan demikian dapat dikatakan bahwa Produk Domestik Bruto sektor pertanian berpengaruh besar pada peningkatan penyerapan tenaga kerja sektor pertanian di Indonesia.

4) Secara umum Produk Domestik Bruto mempunyai pengaruh yang signifikan terhadap penyerapan tenaga kerja sektor pertanian. Hal ini terlihat dari hasil pengujian hipotesis yang ditunjukkan oleh signifikan pada $\alpha=$ 0,000 yang ditujukan oleh $\mathrm{p}$ value sebesar 0,001 atau signifikan pada confidence interval 99 persen dengan pengaruh positif terhadap penyerapan tenga kerja sektor pertanian.

\section{Hubungan Pertumbuhan Sektor Pertanian Terhadap Distribusi Pen- dapatan}

Pengaruh produk domestik bruto sektor pertanian terhadap distribusi pendapatan di Indonesia dalam kurun waktu 1996-2014, menunjukkan bahwa distribusi produk domestik bruto sektor pertanian berpengaruh positif terhadap distribusi pendapatan. Semakin tinggi tingkat pertumbuhan Produk Domestik Bruto sektor pertanian, maka kesenjangaan distribusi pendapatan akan semakin melebar.

Hasil penelitian ini tidak sesuai dengan hasil penelitian Fakri (2009) yaitu tidak ada ada pengaruh antara pertumbuhan sektor pertanian tehadap distribusi pendapatan. namun mendu- kung penelitian yang dilakukan oleh Rufaida (2009) bahwa Nilai Rasio modal berpengaruh secara signifikan pada taraf uji 30 persen terhadap distribusi pendapatan.

Pengaruh yang positif terhadap kesenjangan pendapatan disebabkan telah adanya perubahan dalam penggunaan faktor produksi yang terjadi di sektor pertanian dengan pemanfaatan modal lebih besar dibandingkan dengan penggunaan tenaga kerja, dampaknya penggunaan jam kerja dan jumlah tenaga kerja lebih sedikit yang akhirnya beralih pendistribusian pendapatan untuk penggunaan modal yang seharusnya diterima oleh tenaga kerja, pengaruh ini sangat kecil.

\section{Hubungan Pertumbuhan Sektor Pertanian Terhadap Kesempatan Kerja}

Dari hasil pengolahan data untuk menganalisa pengaruh produk domestik bruto sektor pertanian terhadap penyerapan tenaga kerja sektor pertanian di Indonesia dalam kurun waktu 1996-2014, menunjukkan bahwa produk domestik bruto sektor pertanian berpengaruh positif terhadap penyerapan tenaga kerja sektor pertanian. Semakin tinggi tingkat pertumbuh Produk Domestik Bruto sektor pertanian, maka semakin banyak tenaga kerja sektor pertanian yang terserap. penelitianini sesuai dengan yang dilakukan oleh Yamin (2007) PDRB subsektor tanaman pangan, perkebunan, peternakan, kehutanan, dan perikanan memiliki pengaruh signifikan terhadap kesempatan kerja pada sektor pertanian di Provinsi Sumatera Selatan.

Dari hasil penelitian menunjukkan pertumbuhan sektor pertanian berpengaruh positif terhadap penyerapan tenaga kerja. permasalahan pengangguran dan pertumbuhan angkatan kerja yang terjadi di Indonesia salah satu solusi jawabannya adalah 
dengan meningkatkan pembangunan sektor pertanian. di sisi lain juga sektor pertanian ini mempunyai ketangguhan dalam gonjang-ganjing ekonomi seperti krisis moneter yang terjadi pada tahun 1997-1998 namu pertumbuhan PDRB sektor pertanian dan penyerapan tenaga kerja tetap tinggi dan tidak terpengaruh oleh situasi.

\section{KESIMPULAN, IMPLIKASI, SARAN, DAN BATASAN}

Nilai konstanta gini ratio sebesar 0,316 yang artinya apabila variabel lain tetap maka tingkat ketimpangan distribusi pendapatan masyarakat indonesia berada pada kategori ketimpangan sedang. Selanjutnya PDB sektor pertanian memberikan pengaruh positi dan signifikan terhadap distribusi pendapatan masyarakat, yang ditunjukkan oleh hasil regresi antara PDB dengan gini rasio. PDB memberikan pengaruh sebesar 81,56 persen terhadap distribusi pendapatan di Indonesia.

Apabila terjadi kenaikan PDB sektor pertanian di Indonesia sebesar 1 milyar rupiah, maka akan menyebabkan meningkatnya nilai gini rasio sebesar 0,0000000725, dengan asumsi faktor lain dianggap tetap. Produk Domestik Bruto sektor pertanian berpengaruh besar pada peningkatan penyerapan tenaga kerja sektor pertanian di Indonesia, yaitu sebesar 99 persen terhadap penyerapan tenaga kerja sektor pertanian di Indonesia.

Apabila terjadi kenaikan Produk Domestik Bruto sektor pertanian di Indonesia sebesar 1 milyar rupiah, maka akan menyebabkan meningkatnya penyerapan tenaga kerja sektor pertanian di Indonesia sebesar 21,85 jiwa, dengan asumsi faktor lain dianggap tetap.

Rekomendasi yang dapat disampaikan antara lain: Alokasi mo- dal di sektor pertanian perlu ditingkatkan untuk mendorong penyerapan tenaga kerja dan memperluas kesempatan kerja selain itu juga terpaan krisis moneter tidak mempengarui pertumbuhan ekonomi sektor pertanian dan penyerapan tenaga kerjanya, sehingga sangat mendukung pembangunan ekonomi jangka panjang.

Meningkatkan daya saing komoditi-komoditi pertanian sehingga mampu bersaing dalam pasar Masyarakat Ekonomi Asean (MEA), melalui teknologi produksi pertanian, teknologi hasil pertanian.

Rekomendasi terakhir adalah perlunya penelitian selanjutnya mengenai pembangunan sektor pertanian agar tersedia data dan informasi yang lebih luas menyangkut pengaruh pertumbuhan sektor pertanian terhadap perekonomian.

\section{DAFTAR PUSTAKA}

Badan Pusat Statistik. (2016). Statistik Indonesia Tahun 2016. Jakarta

Dumairy. (1996). Perekonomian Indonesia. Jakarta: Penerbit Erlangga

Fakih, Asrul. (2009). Pengaruh Pembangunan Sektor Pertanian Terhadap Kesempatan Kerja dan Distribusi Pendapatan di Provinsi Jawa Tengah. Skripsi, FE UNNES. Semarang

Sagir, Soeharsono. (1995). Sumber Daya Manusia, Kesempatan Kerja, dan Pembangunan Indonesia. Jakarta: . LPFE-UI

Setyabudi, Heru. (2005). Pengaruh Pertumbuhan PDRB Terhadap Elastisitas KesempatanKerja di Sumatera Selatan. Tesis. Program Pascasarjana. UNSRI. Palembang. 
Rompas J, Engka D, Tolosang K. (2015). Potensi sektor pertanian dan pengaruhnya terhadap penyerapan tenaga kerja di Kabupaten Minahasa Selatan. Jurnal Berkala Ilmiah Efisiensi 15 (04) : 124-136.

Rufaida, Erlina. dan Sari, Dwi Wulan (2006). Analisis Produk Domestik Regional Bruto Sektor Pertanian dan Hubungannya dengan Kesempatan Kerja Serta Distribusi Pendapatan Di Provinsi Sumatera Selatan. Jurnal Pascasarjana Universitas Sriwijaya

Sukirno, Sadono. (2004). Makroekonomi, Teori Pengantar. PT. Raja Grafindo Persada. Jakarta

Yamin, M. (2007). Analisis Pengaruh Pembangunan Sektor Pertanian Terhadap Distribusi Pendapatan dan Peningkatan Lapangan Kerja di Provinsi Sumatera Selatan. Error! Hyperlink reference not valid. 